\title{
PELATIHAN BISNIS ONLINE SHOP UNTUK MENINGKATKAN PRODUKTIVITAS PEMUDA KARANG TARUNA DI DUSUN PATRAN, DESA SAMBILAWANG, BUNGKAL, PONOROGO.
}

\author{
Desi Nur Safitri, Dwi Setya Nugrahini
}

Fakultas Ekonomi Dan Bisnis Islam, IAIN Ponorogo

Email: Desinursafitri2330@gmail.com,dwiita79@yahoo.com

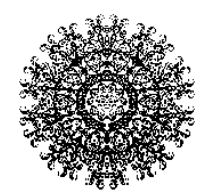

\begin{abstract}
ABSTRAK
Online shop merupakan metode pembelian jasa atau barang para penjual produk, para penjual dan pembeli melakukan interaksi jual-beli tidak bertemu secara langsung atau menyebabkan interaksi fisik, sehingga barang diperdagangkan melalui display dengan gambar di website atau tokomaya. Dalam rangka untuk menjadikan remaja karang taruna Dusun Patran, Desa Sambilawang, Kecamatan Bungkal, Kabupaten Ponorogo tetap produktif, mahasiswa KPM-DDR IAIN Ponorogo memberikan pelatihan tentang usaha online shop kepada para remaja karang taruna. Dengan tujuan dari pelatihan ini yaitu agar para pemuda karang taruna Dusun Patran, Desa Sambilawang, Kecamatan Bungkal, Kabupaten Ponorogo tetap produktif meskipun saat pandemi dan dirumah saja seperti saat ini. Adapun metode penelitian yang dipakai oleh pengabdi pada kegiatan yaitu Asset Based Community Development (ABCD), pengabdi mengutamankan penggunaan kekayaan dan kekuatan di sekitar. Kegiatan pelatihan yang telah dikerjakan diperoleh hasil yaitu: a) kegiatan pelatihan usaha online shop guna meningkatkan produktivitas pemuda karang taruna Dusun Patran, Desa Sambilawang, Kecamatan Bungkal, Kabupaten Ponorogo berjalan dengan lancar. b) dalam pelatiban usaha online shop ini para peserta pelatiban diberikan pengetabuan tentang cara bejualan dan promosi yang baik dan menarik di media sosial whatsapp, instagram, dan facebook.
\end{abstract}

Kata Kunci: Pemuda Karang Taruna, Produktivitas, $A B C D$

\begin{abstract}
Online shop is process purchasing services or goods product sellers, sellers and buyers conduct buying and selling interactions that do not meet directly or motivate physical interaction, so that the goods traded through displays with images on website or virtual store. In order to make youth youth groups in Patran Hamlet, Sambilawang Village, Bungkal District, Ponorogo Regency remain productive, KPM-DDR LAIN Ponorogo students provide training on online shop business to youth youth. With the aim of this training, the youth youth organizations in Patran Hamlet, Sambilawang Village, Bungkal District, Ponorogo Regency can remain productive even during the pandemic and at home as they are now. The research method used by researchers in this activity is Asset Based Community Development ( $A B C D)$, the authors prioritize the use of assets and potentials around. Training activity that have been finish off, the results obtained are: a) online shop business training activities to increase the productivity of youth youth in Patran Hamlet, Sambilawang Village, Bungkal District, Ponorogo Regency are running smoothly. b) In this online shop business training,
\end{abstract}


the training participants are given knowledge about good and attractive selling and promotions on social media Whats App, Instagram, and Facebook.

Keywords: Youth Organization, Productivity, $A B C D$

\section{PENDAHULUAN}

Dunia saat ini, tidak terkecuali di Indonesia sedang menghadapi pandemi, sehingga aktivitas kehidupan masyarakat harus dibatasi. Adanya wabah ini mengharuskan semua masyarakat menjalankan kegiatannya dirumah saja. Akibat dari pandemi ini banyak para karyawan yang harus kehilangan pekerjaanya karena banyaknya perusahaan yang mengurangi jumlah sumber daya nya. Sehingga banyak masyarakat yang menjadi pengangguran. Agar tetap mendapatkan penghasilan dan tetap berada dirumah, masyarakat banyak mengalihkan profesinya yang sebelum pandemi bekerja terjun langsung ke lapangan, maka saat pandemi mereka menjalankan usahanya melalui media online. Dari informasi yang diperoleh melalui iPrice, banyak pemakai marketplace pada kuartal ketiga tahun 2020 mengalami peningkatan daripada kuartal ketiga 2019. Diketahui kuartal ketiga 2019 banyaknya pemakai Shopee ialah sebesar 55,9 juta pengguna, sedangkan pada 2020 pemakai Shoppe sebesar 96,5 juta / berkembang kira-kira 72\%. Marketplace Tokopedia pun memperlihatkan jumlah yang menyerupai. Pemesanan lewat e-commerce melonjak 18,1\% setara dengan 98,3 juta penjualan serta jumlahnya sebanyak $\$ 1,4$ juta USD. Berlandaskan hasil penelitian dari RedSeer dijelaskan terdapat kira-kira 12 juta pemakai e-commerce baru ketika masa pandemi. ${ }^{1}$

Dengan adanya metode berbelanja dengan menggunakan internet tentu memberikan manfaat tersendiri bagi masyarakat, apa lagi dimusim pandemi seperti saat ini. Beberapa dampak positif pada masyarakat mengenai adanya online shop yaitu menjadikan aktivitas jual beli semakin sederhana serta efektif. Karena para pembeli bisa menghemat waktu serta anggaran dalam berbelanja barang yang diminati. Bukan cuma dirasakan oleh pembeli, penjual juga akan merasakan manfaat dari adanya teknologi berjualan melalui media. Manfaat yang dapat dirasakan oleh para penjual yaitu, dengan adanya online shop para penjual relatif membutuhkan modal yang kecil.

1 Sirclo. 2020. Jumlah Pengguna E-Commerce Indonesia di Tabun 2020 Meningkat Pesat. https://www.siclo.com/jumlah-pengguna-e-commerce-indonesia-di-tahun-2020-meningkat-pesat, Diakses pada Rabu, 14 Juli 2021, pukul 18.34. 
Karena untuk menawarkan dan mempromosikan produknya para penjual hanya memanfaatkan jaringan internet saja. Manfaat lainnya yaitu kesedaraan saat menjalankan transaksi jual beli. Saat konsumen telah mendapatkan barang yang diinginkan kemudian terjadilah prosedur jual beli. Pada prosedur jual beli konsumen dan penjual tidak perlu bertemu, pembeli cukup mengirimkan uang sesuai dengan harga barang. Setelah penjual menerima uang yang telah di kirimkan oleh pembeli, maka penjual dapat segera melakukan pengiriman barang sesuai alamat yang diberikan oleh pembeli. ${ }^{2}$

Seiring perkembangan zaman saat ini, banyak anak muda yang tidak bekerja apalagi saat pandemi seperti ini. Banyak anak muda yang menganggur dan tidak memiliki penghasilan sendiri. Ada beberapa anak muda yang masih terus melanjutkkan sekolahnya hingga perguruan tinggi, namun tidak sedikit anak muda yang hanya menamatkan pendidikannya hingga SMA saja atau bahkan hanya menamatkan pendidikannya hingga SMP saja. Seperti para pemuda didusun Patran, desa Sambilawang, kecamatan Bungkal, kabupaten Ponorogo. Pemuda-pemudi terhimpun pada karang taruna tersebut banyak yang belum mempunya pekerjaan, adapun beberapa yang memang masih terus melanjutkan pendidikan ada juga yang berhenti bekerja karena pandemi ini. Hal ini lah yang menjadikan tingkat kreativitas dan produktivitas pemuda-pemuda dusun Patran rendah. ${ }^{3}$

Organisasi kepemudaan yang biasanya ada pada daerah Indonesia salah satunya ialah karang taruna. Organisasi tersebut berfungsi sebagai tempat untuk mengembangkan kaum milenial/muda non-partisipan dengan berlandaskan pemahaman serta responsibilitas sosial dari, oleh dan untuk rakyat utamanya kaum pemuda. Karang taruna biasanya terdiri dari pemudi serta pemuda yang umur anggotanya sekitar 11-45 tahun sedangkan untuk pengurusnya berusia 17-35 tahun. ${ }^{4}$ Didirikannya karang taruna berjutuan untuk membagikan pengajaran serta pengembangan kepada remaja dibidang berorganisasi, keolahragaan, keahlian, agama dan seni. Karang taruna juga dapat dikatakan sebagai wadah untuk mengembangkan

2 Irmayani Syafitri. Ternyata, Inilah Pengertian Online Shop, Manfaat Beserta Kelebihan dan Kekurangan Online Shop. https://www.nesabamedia.com/pengertian-online-shop/, Diakses pada Jum'at, 13 Agustus 2021, pukul 15:15.

${ }^{3}$ Hasil Wawancara dengan Bapak Sumadi.

4 Wikipedia. 2021. "Karang Taruna". https://id.m.wikipedia.org/wiki/Karang_Taruna, diakses pada Senin, 12 Juli 2021, pukul 17.23. 
dan membina para pemuda melalui kegiatan-kegiatan positif yang dilakukan oleh organisasi itu sendiri.

Dengan kemajuan teknologi dan adanya organisasi yang bertujuan untuk mengembangkan dan memberdayakan para pemuda, diharapkan para pemuda sekarang ini dapat lebih bertanggung jawab terhadap lingkungan, terwujudnya kesatuan dan kesejahteraan para generasi muda, terjalinnya kolaborasi positif dalam masyarakat, serta mampu menambah informasi serta wawasan bagi para pemudaa saat ini. Keberadaan pemuda sebagai potensi kekayaan bangsa yang harus diperkuat untuk kebaikan pada masa yang akan datang. Jika para pemuda tidak dikelola secara tepat maka di masa mendatang di khawatirkan dapat menghambat pembangunan dan akan menjadi beban untuk negara. Oleh karena itu diperlukan pengembangan bakat para pemuda melalui kegiatan yang bermanfaat dan produktif.

Dengan kemudahan mengakses internet saat ini, termasuk di Dusun Patran, Desa Sambilawang, Kacamatan Bungkal, Kabupaten Ponorogo tentu dapat dimanfaatkan oleh masyarakat untuk menunjang semua kegiatan yang berbasis internet atau bahkan membuat kegiatan atau aktivitas baru yang memanfaatkan internet. Tentu aktivitas yang dibuat dapat mendatangkan manfaat bagi masyarakt tersebut. Terutama bagi anak muda, dalam kondisi pandemi seperti ini dan saat semua kegiatan formal seperti sekolah di lakukan dengan cara daring, tentu menjadikan para pemuda ini kurang kegiatan dan tentunya menjadikan mereka kurang produktif saat ini. Sehingga dengan kemudahan akses internet dan banyaknya media sosial saat ini, para pemuda perlu di beri pengarahan untuk memanfaatkan peluang tersebut sebaik-baiknya. Dengan kemudahan teknologi dan media sosial saat ini diharapakn para pemuda lebih produktif meskipun saat pandemi seperti ini kegiatan mereka harus dibatasi.

Produktivitas menurut Yuniarsih dan Suwanto yaitu produk nyata yang diperoleh individu/kelompok, dalam jangka khusus dengan prosedur kerja. Adapun pendapat Hasibun tentang produktivitas yaitu menunjukkan adanya bentuk tingkatan efisieansi prosedur pewujudan pada sumber daya yang digunakan, bernilai lebih baik menggunakan upaya yang setara. Secara teknis produktivitas berdasarkan tingkat 
keberhasilan serta efesiensi dalam memanfaatkan beragam sumber daya. Dalam arti pelaku produktivitas ialah perilaku psikis yang selalu berupaya menjadi lebih baik. ${ }^{5}$

Menurut Suryadi, minimnya tingkat kontribusi pemuda pada pengembangan negara adalah permasalah yang dapat diselesaikan dengan pengerjaan programprogram pembangunan berdasarkan peraturan dari badan legislatif. Upaya yang dilakukan pada pembangunan tersebut berguna dalam peningkatan kontribusi warga negara seperti pengembangan pemuda, memperkuat kelembagaan seperti meningkatkan singkronisasi antar sektor serta lembaga. ${ }^{6}$

Organisasi karangtaruna di dusun Patran, desaa Sambilawang, kecamatan Bungkal, kabupatn Ponorogo ini bertugas untuk membantu masyarakat yang membutuhkan bantuan. Para pemuda karang taruna Dusun Patran, Desa Sambilawang, Kecamatan Bungkal, Kabupaten Ponorogo akan selalu ikut serta dalam setiap kegiatan kemaasyarakatan meskipun tidak semua anggota ikut, tetapi kebanyakan anggota karang taruna ikut serta dalam kegiatan kemasyarakatn tersebut. Namun, saat pandemi seperti ini kegiatan kemasyarakatan di Dusun Patran, Desa Sambilawang, Kecamatan Bungkal, Kabupaten Ponorogo tidak boleh dihadiri oleh banyak orang bahkan ada beberapa kegiatan kemasyarakatan yang dihentikan. Hal ini juga terjadi pada kegiatan karang taruna, kegiatan karang taruna seperti arisan rutin setiap bulan juga dihentikan untuk sementara waktu.

Dengan keadaan ini menjadikan produktivitas para pemuda karang taruna menurun. Sehingga untuk menjadikan pemuda karang taruna Dusun Partan, Desa Sambilawang, Kecamatan Bungkal, Kabupaten Ponorogo tetap produktif pengabdi mencoba mengenalkan tentang usaha online yang dilakukan melalui kegiatan pelatihan usaha online di Dusun Patran, Desa Sambilawang, Kecamatan Bungkal, Kabupaten Ponorogo. Yang mana kegiatan tersebut bertujuan untuk mengenalkan tentang usaha online agar selama pandemi ini para anggota karang taruna tetap produktif meskipun dirumah saja.

5 Tri Pitara Mahanggoro. 2018. Melejitkan Produktivitas Kerja dengan Sinergisitas Kecerdasan (ESPQ) tinjauan studi Ilmu Kesehatan. Yogyakarta: CV Budi Utama, hal. 116.

${ }^{6}$ Suryadi Denrich.2018. Gambaran Konflik Emosional dalam Menentukan Prioritas peran Ganda. Jurnal Psikologi. Vol.1, No.1, hal 12. 


\section{METODE}

Pelatihan dalam pengabdian ini pengabdi memakai pendekatan Asset Based Community Development (ABCD) dimana pengabdi mengutamankan penggunaan aset kekayaan sekitar milik masyarakat. Penelitian menggunakan metode berbasis aset ialah membangun suatu ikatan/hubungan. Hal tersebut yang menjadi dasar penemuan suatu ikatan dilingkungan, serta dapat mendukung dalam pembangunan ikatan baru dengan sekelilingnya dan hadiah bisa dialokasikan. ${ }^{7}$

Pendekatan ABCD merupakan pendekatan pelatihan masyarakat yang difokuskan pada potensi masyarakat yaitu melakukan aktivitas pada lingkup dusun, desa, kecamatan serta kabupaten. ${ }^{8}$ Aset desa yang diambil oleh pengabdi dalam pengabdian ini yaitu, karang taruna. Yang mana banyak para remaja Dusun Patran, Desa Sambilawang, Kecamatan Bungkal, Kabupaten Ponoro yang ikut bergabung dalam perkumpulan karangtaruna. Karangtaruna sangat penting keberadaan didusun Patran, desa Sambilawang, kecamatan Bungkal, kabupaten Ponorogo dapat digunakan sebagai alat penyalur potensi dan aspirasi serta menjalin hubungan yang baik antar pemuda. Selain itu dengan adanya organisisa karangtaruna di dusun Patran, desa Sambilawang, kecamatan Bungkal, kabupaten Ponorogo dapat memberikan pendidikan serta kebiasaan kepada para pemuda untuk selalu menjalankan kegiatan desa dengan gotong royong.

Karena kegiatan karang taruna saat pandemi ini banyak yang di hentikan, maka dalam rangka tetap menjadikan para pemuda karang taruna Dusun Patran, Desa Sambilawang, Kecamatan Bungkal, Kabupaten Ponorogo agar tetap produktif salah satu progam kegiatan pengabdian masyarakat ini yaitu melakukan pelatihan tentang bisnis online. Tujuan dari pelatihan bisnis online ini salah satunya yaitu agar dapat menjadikan para pemuda Dusun Patran, Desa Sambilawang, Kecamatan Bungkal, Kabupaten Ponorogo tetap produktif meskipun banyak kegiatan karang taruna yang di hentikan. Dalam kegiatan pemberian pelatihan bisnis online ini, sasaran utamanya yaitu para pemuda wanita Dusun Patran, Desa Sambilawang, Kecamatan Bungkal, Kabupaten Ponorogo. Berdasarkan observasi awal, pengabdi

${ }^{7}$ Al Barret. 2013. Asset Based Community Development: A Theological Reflection. Birmingham Vicar of Hodge Hill Chrunch, hal 2.

${ }^{8}$ Nurul Asmi Pratiwi.2020. Sosialisasi dan Pendampingan Model Pembelajaran Jarak Jauh (Online) di Masa Pandemi. IAIN Parepare Nusantara Press:Sulawesi Selatan, hal 216. 
memutuskan untuk mengadakan pelatihan tentang online shop guna untuk meningkatkan produktivitas pemuda karang taruna Dusun Patran, Desa Sambilawang, Kecamatan Bungkal, Kabupaten Ponorogo utamanya di masa pandemi seperti saat ini.

Dari penjelasan di atas, langkah yang digunakan oleh pengabdi untuk menemukan aset pada dusun Patran, desa Sambilawang, kecamatan Bungkal, kabupaten Ponorogo yaitu dengan menggunakann cara pemetaan komunitas/community mapping. Pengertian dari community mapping yaitu penggambaran pemahaman serta tanggapan masyarakat yang memotivasi pembagian informasi yang setara pada seluruh masyarakat dalam ikut berkontribusi pada proses pengelolaan lingkungan kehidupannya. Community Mapping berfungsi sebagai a) Membenahi dan mengembangkan keterlibatan publik pada pemetaan. b) Membagikan kepada masyarakat dan anggotanya keleluasaan dalam menilai proposal desain, perancangan serta mengambarkan akibat dari keputusan itu kepada masadepan perkumpulan. c) Penghimpunan serta peningkatan data geospasial. d) Mengembangkan pemahaman kelompok mengenai wilayahnya. ${ }^{9}$

Adapun tahapan pelaksaan yang dilakukan oleh pengabdi untuk melakukan penyuluhan masyarakat di dusun Patran, desa Sambilawang, kecamatan Bungkal, kabupaten Ponorogo yaitu:

a. Inkulturasi (Perkenalan).

Dalam tahap ini pengabdi meminta izin serta memberitahukan maksud dan tujuan kedatangan peneliti di Dusun Patran, Desa Sambilawang, Kecamatan Bungkal, Kabupaten Ponorogo yaitu untuk melakukan kegiatan KPM-DDR. Hal ini bermaksud agar masyarakat memahami maksud dan tujuan dari kegiatan dari KPM-DDR, membangun kepercayaan masyarakat, serta agara masyarakat memberikan dukungan terhadap kegiatan KPM-DDR ini.

b. Discovery (Mengungkap Informasi).

Dalam hal ini pengabdi mencari dan menemukan keberhasilan apa yang telah di raih masyarakat pada waktu dahulu, lalu elemen pendukung kesuksesan itu, dan seseorang yang berkontribusi penting atas kesuksesannya.

9 Ahmadi.Pedoman Kuliah Pengabdian Masyarakat Daring Dari Rumah (KPM-DDR).Ponorogo: LPPM, 2021, hal 54. 
c. Design (Melihat Aset serta Mengenali Peluang).

Dalam tahap tersebut pengabdi mencari informasi baik melalui observasi atau wawancara dengan pihak terkait tentang aset serta peluang pada dusun Patran, desa Sambilawang, kecamatan Bungkal. Hal ini bertujuan untuk memberikan kekuatan positif terhadap masyarakat, agar mengetahui peluang yang ada di dusun mereka yang mungkin belum mereka ketahui. Dalam hal ini diharapkan masyarakat dapat berkontribusi dalam kegiatan.

d. Define (Mendukung Keterlaksanaan Progam Kerja).

Dengan data aset yang telah dimiliki oleh pengabdi dihararapkan masyarakat mampu mengetahui aset sekeliling meraka yang bertujuan mengembangkan kehidupan masyarakat dimasa yang akan datang. Sehingga masayarakat bisa mendukung serta berpartisipasi dalam kegiatan ini.

e. Refelection (Refleksi).

Pada tahapan ini diketahui bahwa pendekatan ini memerlukan adanya baseline, mengawasi pengembangan, juga outcome. Dalam hal ini kegiatan berganti bukan lagi tentang separuh gelas kosong dapat di isi, melainkan tentang separuh gelas penuh dikelola.

\section{HASIL DAN PEMBAHASAN}

Melalui hasil pengamatan, survei, serta interview yang sudah dilakukan pengabdi diperoleh hasil banyak pemuda di Dusun Patran, Desa Sambilawang, Kecamatan Bungkal, Kabupaten Ponorogo yang bergabung dalam organisasi karangtaruna, dan sebagai salah satu aset dusun Patran, desa Sambilawang, kecamatan Bungkal, kabupaten Ponorogo. Berasal dari penelitian yang telah dikerjakan, pengabdi menemukan masalah yaitu dengan dihentikannya kegiatan karang taruna di masa pandemi ini menjadikan para pemuda karang taruna kurang produktif. Oleh karena itu melalui kegiatan KPM-DDR IAIN Ponorogo ini pengabdi ingin mengajak pemuda karang taruna Dusun Patran, Desa Sambilawang, Kecamatan Bungkal, Kabupaten Ponorogo untuk tetap produktif meskipun banyak kegiatan karang taruna yang di hentikan. Adapun kegiatan yang dibuat oleh pengabdi yaitu pelatihan usaha online shop guna meningkatkan produktivitas pemuda karang taruna Dusun Patran, Desa Sambilawang, Kecamatan Bungkal, Kabupaten Ponorogo. 
Dalam pelaksanaan kegiatan pelatihan ini terdapat beberapa tahapan, yakni, inkulutrasi, assement, kegiatan inti pelatihan, dan evaluasi setelah pelatihan. Tahap pertama yaitu inkulturasi, pada tahap ini pengabdi melakukan silahturahmi dengan kepala desa dan staff desa untuk menyampaikan maksud dan tujuan kedatangan pengabdi di Desa Sambilawang, Kecamatan Bungkal, Kabupaten Ponorogo.

Pada tahap keduan yaitu assement, dari hasil assement diperoleh informasi terkait peserta pelatihan, lokasi pelaksanaan kegiatan pelatihan, dan strategi pelaksanaan pelatihan. Hal selanjutnya yang dilakukan oleh pengabdi yaitu mengundang para pemuda karang taruna untuk mengikuti pelatihan yang akan di laksanakan. Tahap ketiga yaitu kegiatan inti pelatihan. Pelatihan dilaksanakan pada tanggal 02 agustus 2021 di mushola yang mana kegiatan pelatihan usaha online shop ini di isi oleh narasumber yang telah disediakan oleh pengabdi. Dalam pelatihan ini pengadbi mendatangkan dua narasumber, yaitu saudari Candra dan saudari Deya. Kedua narasumber tersebut merupakan mahasiswa IAIN Ponorogo yang telah menjalankan bisnis online shop sejak lama dan telah mendapatkan banyak keuntungan. Kegiatan pelatihan diikuti oleh 2 orang, karena adanya pandemi dan peraturan PPKM dari pemerintah, sehingga pelatihan tidak bisa diikuti oleh banyak orang. Acara pelatihan dimulai pada pukul 09.00 WIB hingga pukul 11.00 WIB. Pada season pertama pelatihan dibuka dengan sambutan atau pengarah dari pengabdi, lalu di lanjutkan oleh narasumber untuk menyampaikan materi dan memberikan pelatihan kepada peserta. Setelah semua materi disampaikan, maka dibukalah season tanya jawab antara para peserta dengan narasumber. Setelah sesi tanya jawab selesai, pelatihan ditutup oleh pengabdi.

Tahap yang terakhir yaitu evaluasi pasca kegiatan yang bertujuan untuk mengetahui seberasa besar tingkat keberhasilan kegiatan ditinjau dari jumlah kehadiran peserta pelaihan, tercapainya tujuan pelatihan dan ketercapaian target materi yang disampaikan, dan kemampuan peserta dalam menguasai materi yang telah disampaikan oleh para narasumber. Dari tahap ini diketahui bahwa kegiatan pelatihan usaha online shop yang telah dilaksanakan cukup berhasil. Dapat dilihat dari peserta yang hadir dapat memahami materi-materi yang telah disampaikan oleh para narasumber dan dapat menerapkan materi tersebut. Namun, dalam hal jumlah peserta pelatihan ini masih sangat kurang peserta. Dikarenakan dibatasi pesertanya 
dan pemberlakuan PPKM, sehingga pengabdi tidak bisa memaksimalkan peserta pelatihan

\section{Mengenal Tentang Online Shop, Kelebihan dan Kekurangan Online Shop.}

Bisnis online sekarang tidak menjadi hal baru untuk warga Indonesia, bagi yang mahir memakai internet maupun yang belum, yang terbiasa memakai internet maupun tidak. Maksud dari online shop ialah cara belanja jasa dan barang dari para penjual produk dengan melakukan interaksi jual-beli tidak bertemu secara langsung / melaksanakan kontak fisik, sehingga barang dipasarkan menggunakan display yang bergambar pada website. Setelah itu para pelanggan bisa menentukan barang keinginannya, selanjutnya membayar ke penjual menggunakan metode yang disepakati antara kedua belah pihak. Setelah pembayaran diterima maka kewajiban penjual yaitu mengirimkan pesanan produk pembeli sesuai alamat yang diberikan oleh pembeli. ${ }^{10}$

Dengan adanya bisnis online shop tentu mempunyai kelebihan serta kekurangan diantaranya sebagi berikut: ${ }^{11}$ Kelebihan bisnis online shop:

a. Jangkauannya luas. Dengan adanya kemajuan teknologi saat ini menjadikan jaringan internet dan jasa ekspedisi barang dapat menjangkau banyak pelanggan meskipun berbeda negara.

b. Hemat biaya. Dalam bisnis online shop pegawai yang dibutuhkan relatif lebih sedikit jika dibandingkan dengan usaha tradisional. Hal ini dikarenakn pada bisnis online shop sebagian tugas dibantu oleh perangkat lunak. Selain itu bisnis online shop juga tidak membutuhkan lokasi fisik seperti toko dan juga tidak membutuhkan tempat tertentu. Hanya meminjam gudang/rumah pribadi sebagai tempat penyimpanan dagangan.

c. Informatif. Penjelasan produk promosi dijelaskan secara lengkap memakai gambar serta kalimat yang membujuk calon pembeli. Deskripsi dari produk dapat berupa penjelasan yang sering di ajukan pembeli serta waktu pengoperasionalan pekerjaan.

${ }^{10}$ Hestanto, Teori Online Shop Menurut Beberapa Abli. https://www.hestanto.web.id/onlineshop/iakses pada Jum'at, 13 Agustus 2021, Pukul 17:03.

11 Agus Wibowo, Internet Marketing. (Yogyakarta: CV. ANDI OFFSET, 2017), 2-3. 
d. Beroperasi 24 jam dalam sehari dan 7 hari seminggu menggunakan metode pembayaran dan pengiriman secaraotomatis. Jual beli produk dapan dilakukan kapan pun dan dimana pun. ra konsumen dapat melakukan pembelian barang sesuai dengan kemauannya.

e. Menaikkan visibilitas bisnis menggunakan optimalisasi mesin pencari serta advertensi online. Dengan bisnis online shop menjadikan para konsumen lebih mudah untuk mencari produk yang ditawarkan oleh para pembeli.

Kekurangan bisnis online shop:

a. Harga barang lebih mahal. Barang-barang yang dijual melalui media online relatif lebih mahal. Hal ini dikarenakan oleh biaya jasa pengiriman diberikan ke barang yang dibeli pada penjual yang beralamat luar kota/provinsi.

b. Persangingan yang semakin berat. Semakin hari banyaknya orang yang melakukan bisnis online shop semakin meningkat dan diperlukan pembelajaran serta selalu melakukan trobosan baru supaya bertahan juga bertumbuh dalam memerangi lawan dan pengembangan teknologi baru.

Dalam hal ini pengabdi melalui narasumber yang telah disediakan menjelaskan arti dari bisnis online shop. Selain itu narasumber juga menjelaskan tentang kelebihan dan kekurangan dari bisnis online shop. Hal ini merupakan tahapan awal, yaitu pengenalan tentang bisnis online shop kepada peserta pelatihan. Tujuannya yaitu agar para peserta pelatihan lebih mengetahui dan memahami tentang bisnis online shop.

\section{Pelatihan Melakukan Promosi Produk Melalui Media Online.}

Pelatihan yaitu sebuah proses belajar tentang sesuatu ketrampilan tertentu yang dibutuhkan untuk mengerjakan suatu pekerjaan atau aktivitas tertentu. Kata kunci dari pelatihan adalah adanya proses belajar, untuk membentuk suatu kecakapan baru. Definisi lain dari pelatihan yaitu tindakan mengajari seseorang atau binatang suatu ketrampilan khusus. Fokus kepada pelatihan adalah membentuk perilaku spesifik, sesuai dengan tujuan pelatihan tersebut. ${ }^{12}$ Menurut Widodo pelatihan ialah kumpulan kegiatan pribadi bagi peningkatan keahiran serta pemahaman terstruktur agar bisa memaksimalkan kinerja professional pada bidang tertentu. Pelatihan ialah sistem pendidikan yang menjadikan pekerja melakukan pekerjaan setara standarnya.

12 Neila Ramdahni, dkk.Psikologi Untuk Indonesia Tangguh Dan Bahagia.Yogyakarta: Gadjah Mada University Press, 2018, Hal 108. 
Rivai dan Sagala mengungkapkan pelatihan ialah cara teratur dalam merubah perilaku pekerja dalam pencapaian tujuan. Pelatihan berhubungan kemahiran serta keterampilan pekerja dalam mengerjakan pekerjaannya. ${ }^{13}$

Kesimpulannya pelatihan merupakan suatu sistem berguna untuk meningkatkan kompetensi seseorang agar dapat mencapai tujuan organisasi, pelatihan juga dapat dikatakan sebuah proses pembelajaran untuk mendapatkan serta peningkatan kemampuan seseorang diluar metode pembelajaran dan metode pelatihan yang digunakan adalah memperbanyak praktiknya dibandingkan teori. Dalam sebuah kegiatan yang dilakukan oleh seseorang tentu mempunyai manfaat baik untuk dirinnya sendiri ataupun untuk orang lain. Begitu juga dengan diadakannya suatu pelatihan tentu memiliki maanfaat. Adapun manfaat dari diadakannya pelatihan menurut Henry Simamora yaitu: ${ }^{14}$

a. Peningkatan kualitas serta kuantitas keproduktifan kerja.

b. Pengurangan durasi belajar yang digunakan pada pencapaian standar kinerja.

c. Pembentukan loyalitas, sikap serta kolaborasi positif.

d. Pemenuhan keperluan perancangan SDM.

e. Pengurangan jumlah dan anggaran kecelakaan kinerja.

f. Mendukung pekerja memperbaiki serta pengembangan individu.

Adapun yang dimaksud dengan promosi yaitu, menurut Philip Kotler promosi merupakan sebagai aktivitas perusahaan untuk menyampaikan kegunaan produk serta membujuk pembeli agar membelinya. Menurut Rambat Lupiyadi mendefiniskan promosi sebagai variabel campuran penjualan yang esensial untuk dilaksanakn perusahaan dalam pemasaran produk barang serta jasa. Sedangkan Julian Cummins mendefinisikan promasi ialah kumpulan cara dipakai dalam pencapaian tujuan penjualan memakai anggaran efektif dan mengasih nilai tambahan produk bagi perantara ataupun penggunaan langsung,serta tidak ada batasan jangka waktu. ${ }^{15}$

Definisi yang telah diungkapkan oleh beberapa tokoh tersebut, kesimpulannya promosi ialah sebuah aktivitas yang digunakan sebagai sarana

13 Shinta Juliany.Peranan Pelatiban dan Pengembangan dalam Meningkatkan Kinerja Karyawan PT. Pos Indonesia (Persero) Palembang. Skripsi.Palembang: Politeknik Negeri Sriwijaya, 2015,Hal 9.

${ }^{14}$ Ajabar.Manajemen Sumber Daya Manusia.Yogyakarta: CV. BUDI UTAMA,2020. Hal 23.

15 Freddy Rangkut.Strategi Promosi yang Kreatif \& Analisis Kasus Integrated Marketing Communication.Jakarta: PT. Gramedia Pustaka Utama, 2009.Hal 177. 
komunikasi penjual dengan konsumen. Tidak hanya itu saja promosi juga digunakan oleh penjual sebagai alat untuk mempengaruhi calon pembeli supaya termotivasi membeliproduk yang dijual.

Online Promotion ialah metode/strategi penjualan produk terefektif dikerjakan menggunakan perkembangan teknologi internet. Medsos merupakan alat pemasaran online. Promosi online meruakan kegiatan memasarkan produk jualan yang mana dikerjakan dengan online lewat internet serta teknologi tercanggih. Beberapa portal untuk melakukan online Promotion yaitu: pertama, Facebook ialah platform dengan banyak pengguna dan terus meningkat, populernya facebook di Indonesia dapat digunakan sebagai tempat mengenalkan bisnis seseorang. Tetapi juga dipakai dalam menaikkan traffic website, engagement serta memperoleh leads. Kedua, WhatsApp, sebagian besar pemakai internet khusunya Indonesia memakai whatsapp baik usia anak-anak sampai orang dewasa. Bagi para pelaku usaha, whatsapp adalah platform promosi karena banyak fitur-fitur yang memudah untuk berkomunikasi, seperti chat, panggilan suara, video call, dan whatsapp business. Kegita, instagram. Instagram juga merupakan media sosial yang banyak penggunanya. Dengan menggunakan instagram para pelaku bisnis atau pedagang dapat mempromosikan produknya melalui feed, instagram story, dan IG TV.

Dalam pelatihan ini para narasumber memberikan pelatihan tentang cara melakukan promosi yang baik dan menarik melalui media sosial. Narasumber menjelaskan tentang cara promosi melalui tiga media yaitu, whatsApp, instagram, dan Facebook. Adapun cara-cara yang disampaikan oleh narasumber yaitu:

1. Melakukan promosi saat waktu pagi.

Hal ini dikarenakan ketika pagi hari seseorang belum banyak melakukan pekerjaan dan otak pun masih fresh setelah beristirahat di malam hari. Sehingga memungkinkan untuk tertarik terhadap suatu produk lebih tinggi dibandingkan saat-saat jam kerja.

2. Tidak hanya mengupload foto produk saja.

Maksudnya yaitu ketika pelaku bisnis ingin mempromosikan produknya jangan hanya mengupload gambar saja tanpa deskripsi. Hal ini biasanya akan menjadikan calon pembeli tidak tertarik karena tidak mengetahui detail produk tersebut. 
3. Menggunakan deskripsi yang jelas.

Jika mempromosikan produk melalui internet berilah deskripsi tentang produk dengan lengkap. Mulai dari ukuran, harga, persedian warna lain atau motif lain. Hal tersebut berguna untuk memberi keyakinan kepada calon konsumen tentang barang-barang yang di promosikan tersebut.

4. Hendaknya saat menulis deskripsi atau kata-kata promosi diberikan tambahan emoticon.

Penggunaan emoticon dirasa cukup membantu promosi seseorang, karena dengan tambahan emoticon akan memberikan sugesti bahwa penjual berekpresi sesuai dengan emoticon tersebut.

5. Bergabung dengan group jual beli.

Cara ini dapat dilakukan jika menggunakan media facebook untuk promosi. Jika promosi menggunakan media facebook, maka seseorang dapat bergabung dengan group-group marketplace yang ada di facebook. Hal ini dikarenakan agar banyak orang yang mengetahui usaha anda atau produk anda.

Alasan para narasumber memberikan pelatihan promosi produk melalui media whatsapp, facebook, dan instagram dikarenakan telah banyaknya orang yang mengakes media sosial itu. Selain itu, cara penggunaan ketiga media sosial tersebut cukup mudah untuk dipelajari serta fitur-fitur yang disediakan oleh tiga media sosial tersebut bermacam-macam.

\section{Faktor Pendorong dan Penghambat Kegiatan}

Berdasarkan hasil evaluasi yang ditelah dilakukan oleh pengabdi, diketahui terdapat beberapa faktor pendorong dan faktor penghambat saat dilaksanakannya kegiatan KPM-DDR di Dusun Patran, Desa Sambilawang, Kecamatan Bungkal, Kabupaten Ponorogo ini, yaitu seperti:

a. Faktor Pendorong Kegiatan:

1. Mendapatkan dukungan penuh dari kepada Desa Sambilawang atas pelaksanaan kegiatan KPM-DDR, khususnya dukungan untuk kegiatan pelatihan usaha online shop guna meningkatkan produktivitas remaja karang taruna Dusun Patran, Desa Sambilawang, Kecamatan Bungkal, Kabupaten Ponorogo.

2. Mendapat partisipasi dan antusia yang baik dari para peserta pelatihan, sehingga para peserta pelatihan mengikuti kegiatan pelatihan tanpa adanya paksaan. 
b. Faktor Penghambat Kegiatan:

1. Sulitnya menentukan waktu untuk mengadakan kegiatan pelatihan. Hal ini dikarenakan saat kegiatan KPM-DDR bertepatan dengan diberlakukannya peraturan PPKM oleh pemerintah.

\section{KESIMPULAN}

Berdasarkan uraian dalam pembahasan diatas, dapat diperoleh kesimpulan di antaranya yaitu: (1) dalam pelaksaan kegiatan KPM-DDR di Dusun Patran, Desa Sambilawang, Kecamatan Bungkal, Kabupaten Ponorogo melalui pelatihan bisnis online shop guna meningkatkan produktivitas pemudi karang taruna dapat terlaksana dengan baik. (2) Diadakannya pelatihan ini yaitu menjadikan para pemuda memiliki kegiatan yang bermanfaat. Sehingga para pemudi tetap dapat produktif meskipun hanya dirumah saja. (3) Kegiatan pelatihan ini mengajarkan kepada para pemudi karang taruna tentang cara melakukan promosi melalui media sosial yang baik. Dengan ini diharapkan para pemudi dapat menerapkan pelatihan ini dan mendapatkan manfaatnya.

\section{DAFTAR PUSTAKA}

Ahmadi, (2021). Pedoman Kuliah Pengabdian Masyarakat Daring dari Rumah (KPMDDR). Ponorogo: LPPM.

Ajabar, (2020). Manajemen Sumber Daya Manusia. CV. BUDI UTAMA: Yogyakarta.

Al Barret, 2013. Asset Based Community Development: A Theological Reflection.

Birmingham Vicar of Hodge Hill Chrunch.

Asmi Pratiwi, Nurul, (2020). Sosialisasi dan Pendampingan Model Pembelajaran Jarak Jauh (Online) di Masa Pandemi. Sulawesi Selatan: IAIN Parepare Nusantara Press.

Denrich, Suryadi, (2018). Gambaran Konflik Emosional Dalam Menentukan Prioritas Peran Ganda. Jurnal Ilmiah Psikologi.Vol 1. No.1, hal 12, diakses pada http://repository.untar.ac.id/id.eprint/8817.

Hestanto, (2017). Teori Online Shop Menurut Beberapa Abli. Online. https://www.hestanto.web.id/online-shop/, diakses pada Jum'at, 13 Agustus 2021. 
Juliany, Shinta, (2015).Peranan Pelatiban dan Pengembangan dalam Meningkatkan Kinerja Karyawan PT. Pos Indonesia (Persero) Palembang. Skripsi.Politeknik Negeri Sriwijaya.Palembang. 9. http://eprints.polsti.ac.id/2395/3/BAB\%20II.pdf.

Pitara Mahanggoro, Tri. (2018).Melejitkan Produktivitas Kerja dengan Sinergisitas Kecerdasan (ESPQ) Tinjauan Studi Ilmu Kesehatan. CV. Budi Utama:Yogyakarta.

Rahmat Nizar, Muhammad, (2015). Penggunaan Brosur sebagai Media Iklan dalam Meningkatkan Penjualan pada PT. A\&S Holiday Travel Palembang. Skripsi.Politeknik Negeri Sriwijaya, Palembang.

Ramdahni, Neila, dkk (2018). Psikologi untuk Indonesia Tangguh dan Babagia. Gadjah Mada University Press: Yogyakarta.

Rangkut, Freddy, (2009). Strategi Promosi yang Kreatif \& Analisis Kasus Integrated Marketing Communication. Jakarta: PT. Gramedia Pustaka Utama.

Sirclo, (2020). Jumlah Pengguna E-Commerce Indonesia di Tabun 2020 Meningkat Pesat. https://www.siclo.com/jumlah-pengguna-e-commerce-indonesia-di-tahun2020-meningkat-pesat, di akses pada Rabu, 14 Juli 2021.

TSyafitri, Irmayani, (2019).Ternyata, Inilah Pengertian Online Shop, Manfaat Beserta Kelebihan dan Kekurangan Online Shop. https://www.nesabamedia.com/pengertian-online-shop/, diakses pada Jum'at, 13 Agustus 2021.

Ummul Hidayah, Debby, dkk, (2019). Pelatihan Penjualan Online Untuk Masyarakat Desa Karanglewas Kidul Kabupaten Banyumas. Jurnal Pengabdian Kepada Masyarakat. Vol.2. No.1.

Wibowo, Agus, (2017). Internet Marketing. Yogyakarta: CV. ANDI OFFSET.

Wikipedia, (2021), Karang Taruna. https://id.m.wikipedia.org/wiki/Karang_Taruna, diakses pada Senin, 12 Juli 2021. 